\title{
Supplementation of Purple Sweet Potato Extract on Protein Digestibility and Meat Protein Mass in Broiler Reared Under Different Cage Density
}

\author{
Saputra Y, Suthama N, Sukamto B \\ Faculty of Animal and Agriculture Sciences, Diponegoro University \\ Tembalang Campus, Semarang-50275, Central Java, Indonesia \\ yoga_saputra_@live.com
}

\begin{abstract}
The research was conducted to evaluate supplemental effect of purple sweet potato extract (PSPE) on protein intake, ileum protein digestibility and meat protein mass. The experiment was assigned in a randomized complete design with $2 \times 3$ factorial scheme, 6 treatments and 4 replications. The first factor was cage density (normal density/D1 $=8 \mathrm{birds} / \mathrm{m}^{2}$ and high density/D2 $\left.=16 \mathrm{birds} / \mathrm{m}^{2}\right)$, and the second factor was the extract levels of purple sweet potato $(\mathrm{A} 0=$ control diet, $\mathrm{A} 1$ = diet containing $25 \mathrm{ml} \mathrm{PSPE} / \mathrm{kg}$ feed and A2 = diet containing $50 \mathrm{ml} \mathrm{PSPE} / \mathrm{kg}$ feed). Birds were kept in a brooder cage for 14 days and then transferred to colony cages $(1 \times 1 \mathrm{~m})$ until the age of 35 days. When measurement of protein digestibility the birds were moved to individual battery cage on day 35 . The experimental feed contained $21 \%$ crude protein and metabolizable energy of $3000 \mathrm{kcal} / \mathrm{kg}$. The results showed that the extract of purple sweet potato and cage density did not show significant $(\mathrm{P}>0.05)$ interaction. The supplementation of purple sweet potato extract significantly $(\mathrm{P}<0.05)$ affected protein intake, protein digestibility and meat protein mass, while the cage density affected only the protein digestibility.
\end{abstract}

Key Words: Broiler, Meat Protein Mass, Protein Digestibility, Purple Sweet Potato Extract

\section{INTRODUCTION}

Broiler chickens are livestock demanded by the community and able to fulfill the demand of chicken meat. The high demand of broiler chickens bring about the farmers try to increase the productivity. However, the increase in cage density with the similar amount of space causes the animal more susceptible to stress and it will be more detrimental when the activity of free radicals-oxidative stress exceeds the antioxidant levels (Mahfudz et al. 2015). A way to reduce stress due to very high cage density can be overcome by supplemental antioxidants. Diet contains antioxidants for chickens rear at a high density (20 birds $/ \mathrm{m}^{2}$ ) was more effective to promote growth, to increase antioxidant activity in the body and to reduce the risk of drip loss (Lu et al. 2014).

Natural antioxidants are classified into five categories namely organosulfur compounds, flavonoids, phenolic compounds, carotenoids and vitamins. The natural antioxidants which low molecular weight was effectively to reduce reactive oxygen species (ROS) and to protect the damage due to biomolecular oxidative (Wada et al 2015). Source of antioxidants, especially anthocyanins available in colored fruits such as berries, cherries, peaches, grapes, black currant, and plum as well as many dark colored vegetables such as red onion, red radish, black bean, egg plant, purple corn, red cabbage and purple sweet potato (Baskan et al. 2015).

Purple sweet potato contains anthocyanins and can also be used for livestock feed. In addition, purple sweet potato is always available and affordable price. Antioxidants contained in purple sweet potato are in the form of tocopherol (Vit. E), beta carotene, phenolic acids and anthocyanins. The highest antioxidant in purple sweet potato is anthocyanin is about $6.23 \mathrm{mg} / \mathrm{g}$ dry weight ( $\mathrm{Ji}$ et al 2015). 
The addition of antioxidants such as anthocyanin in the diet was expected to reduce heat stress and improve the health of livestock so that the production increased. The increase in meat production as a result of better animal health was due to the increase in protein consumption and nutrients absorption brought about the higher protein intake which was subtrate for meat deposition. Anthocyanins can also be natural color since the characteristics of constituent compounds are also pigments and water soluble. The main compositions of anthocyanin arrived from purple sweet potato was derivatives of peonidin and cyanidin (4.52:1). The high level of peonidin caused red color while if the sianidin was higher, the dominant color was blue (Montilla et al 2011). Flavonoid compounds also contributed to the calcium absorption which was related to meat protein deposition. This means that the availability of calcium was closely related to the protein in the form of calcium binding protein (CABP) (Syafitri et al. 2015).

The purpose of this research was to evaluate the effect of the different level of feeding purple sweet potato extract on the protein intake, ileum protein digestibility and meat protein mass. It is expected that adding purple sweet potato extracts improve the productivity of broiler chickens by reducing heat stress environmental temperature.

\section{MATERIAL AND METHODS}

\section{Management of the experimental chicks}

A total of 288 broiler DOCs of Lohmann strain were kept in a brooder cage until 14 days of age, at the age of 15 (body weight $393 \pm 10,11 \mathrm{~g}$, with $\mathrm{CV}=2,3 \%$ ) they were transferred to a cage of colony systems $(1 \times 1 \mathrm{~m})$, and when digestibiltity of protein measurement was carried out, at the age of 35 days, two birds of each experimental unit were moved into the battery cage.

\section{Experimental diets}

The extract of purple sweet potato (PSPE) were obtained from the extract of purple sweet potato tuber (Ipomea batatas L.) that was washed and peeled prior to processing. Purple sweet potato used were purple skin and bulb, purchased from farmers in the district of Bandungan, Semarang. Basal diet was formulated containing $21 \%$ crude protein and $3,000 \mathrm{kcal}$ metabolizable energy/kg (Table 1). The feed and water were provided ad libitum.

\section{Treatment and statistical analysis}

The experiment was assigned in a complete randomized design with $2 \times 3$ factorial scheme (4 replications each). The first factor was cage density, namely normal density (D1 $=8$ birds $/ \mathrm{m}^{2}$ ) and high density $\left(\mathrm{D} 2=16 \mathrm{birds} / \mathrm{m}^{2}\right)$, and the second factor was the extract levels of purple sweet potato namely control diet (A0), $25 \mathrm{ml} \mathrm{PSPE} / \mathrm{kg}$ feed (A1) and 50 $\mathrm{ml} \mathrm{PSPE} / \mathrm{kg}$ feed (A2). The combination treatment were as follows: D1A0, D1A1, D1A2, $\mathrm{D} 2 \mathrm{~A} 0$, D2A1 and D2A2. The parameters observed were protein intake, ileal protein digestibility and meat protein mass. Digestibility of protein was done at the ileal level by placing chickens from each treatment into individual cage of battery, then they were given drinking water and feed treatment ad libitum to reduce stress and adaptation, and then were fasted for 12 hours, given dietary treatment thereafter before fasting for another 4 hours and finally they were slaughtered (Foltyn et al. 2015). Digesta was taken by dissection and then stored at $-20^{\circ} \mathrm{C}$. The ileum content was taken from Meckel's diverticulum to $40 \mathrm{~mm}$ 
before cecum branching (Khooshechin et al. 2015). Protein consumption and ileal protein digestibility was calculated based on the formula of Tillman et al. (2005) and Stein et al. (2007), respectively. The calculation of the meat protein mass was according to protein content of the meat. Meat protein mass was calculated based on the formula purposed by Suthama (2003). Data were analyzed based on variance analysis procedure at 5\% significance level. If the treatment indicated significant effects it was continued to Duncan's multiple range tested.

Table 1. Ingredients and nutrient composition of the experimental basal diets

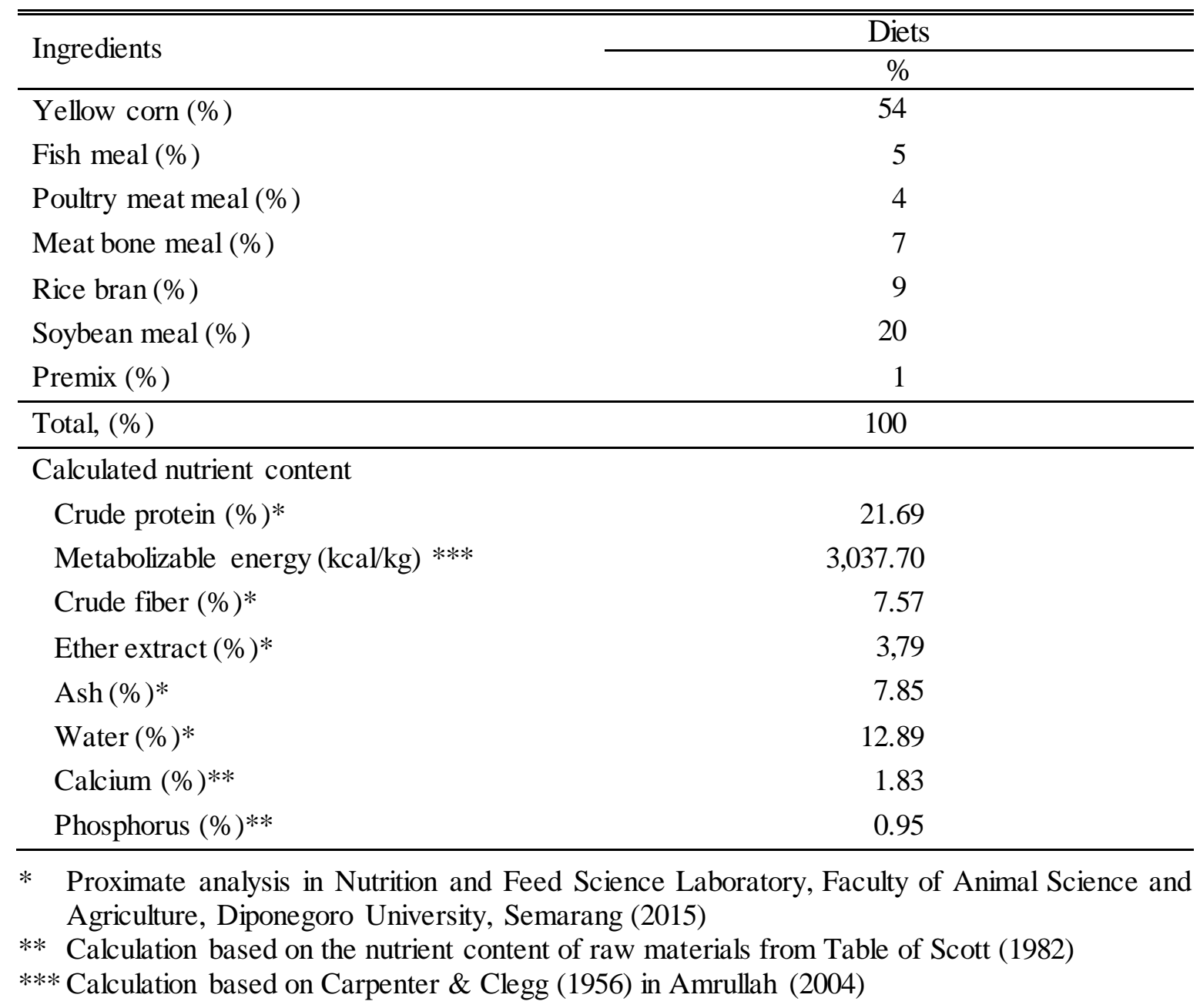

\section{RESULTS AND DISCUSSION}

\section{Protein intake}

The addition of PSPE in broiler chicken diets which were maintained under different cage density is presented in Table 2. There was no interaction between the addition PSPE and cage density. The protein consumption of $\mathrm{A} 0$ was significantly lower $(\mathrm{P}<0.05)$ than those of $\mathrm{A} 1$ and $\mathrm{A} 2$, but there was no difference between that of $\mathrm{A} 1$ and $\mathrm{A} 2$. The differences of the protein consumption was lower in A0 compared to A1 and A2 which were caused by the addition of PSPE that can be assumed due to the changed in texture and color of diets. The change in diet texture from mash into clot like crumble after PSPE addition, the color diet were different from that of basal diet. The shape of the crumble 
diets was preferred by the chicken because diets crumble was more dense and large in size. Brickett et al. (2007); and Lv et al. (2015) reported that chickens which were fed by a crumble diets treatment at 14-35 days of age showed higher feed intake compared with those fed the form of mash diets, because diets with a granular form were more solid so the diets were palatable for poultry.

Table 2.Protein intake, protein digestibility, and meat protein mass of broiler fed supplemental extract of purple sweet potato and reared under different cage density

\begin{tabular}{|c|c|c|c|c|}
\hline \multirow[b]{2}{*}{ Cage density } & \multicolumn{2}{|r|}{ Level PSPE } & & \multirow[b]{2}{*}{ Average } \\
\hline & $\begin{array}{c}\mathrm{A} 0 \\
\text { (Basal) }\end{array}$ & $\begin{array}{c}\text { A1 } \\
\text { (Basal + } 25 \text { ml/kg) }\end{array}$ & $\begin{array}{c}\mathrm{A} 2 \\
(\text { Basal }+50 \mathrm{ml} / \mathrm{kg})\end{array}$ & \\
\hline \multicolumn{5}{|c|}{ Protein intake (g/bird/day) } \\
\hline D1 (8 birds $\left./ \mathrm{m}^{2}\right)$ & 16.72 & 17.00 & 16.90 & $16.87^{\mathrm{a}}$ \\
\hline D2 (16 birds $\left./ \mathrm{m}^{2}\right)$ & 16.70 & 17.02 & 17.18 & $16.97^{\mathrm{a}}$ \\
\hline Average & $16.71^{\mathrm{b}}$ & $17.01^{\mathrm{a}}$ & $17.04^{\mathrm{a}}$ & \\
\hline \multicolumn{5}{|c|}{ Protein digestibility (g Nitrogen/100g intake) } \\
\hline D1 (8 birds $\left./ \mathrm{m}^{2}\right)$ & 10.15 & 10.59 & 10.38 & $10.37^{\mathrm{a}}$ \\
\hline D2 (16 birds $\left./ \mathrm{m}^{2}\right)$ & 9.81 & 10.38 & 10.14 & $10.11^{\mathrm{b}}$ \\
\hline Average & $9.98^{\mathrm{c}}$ & $10.48^{\mathrm{a}}$ & $10.26^{\mathrm{b}}$ & \\
\hline \multicolumn{5}{|c|}{ Meat protein mass (g/bird) } \\
\hline D1 (8 birds $\left./ \mathrm{m}^{2}\right)$ & 139.51 & 154.01 & 143.42 & $145.73^{\mathrm{a}}$ \\
\hline D2 (16 birds $\left./ \mathrm{m}^{2}\right)$ & 138.43 & 162.67 & 140.04 & $147.05^{\mathrm{a}}$ \\
\hline Average & $139.09^{\mathrm{b}}$ & $158.34^{\mathrm{a}}$ & $141.73^{\mathrm{b}}$ & \\
\hline
\end{tabular}

Different superscripts in each average value in the same row or in the same column in each variable are significantly different $(\mathrm{P}<0.05)$

The color of the diet changed from yellow to red after adding PSPE and to be more homogeneous than the basal diets. As it was known that birds in general, or chicken in particular, choosed diets through the eye sensor, so the red diets were more attractive and palatable than others. Rierson (2011) showed that broiler chicken consumed more red diets than yellow diets. The higher feed intake on the red color was because of chicken eyes reach to the peak sensitivity on colors including green, red and blue. The red color was caused by PSPE which contains flavonoids, in particular anthocyanins as color pigment. It was supported by Loetscher et al. (2013) that broiler chickens given diet with the addition of antioxidants containing rosehip and chokeberry in the form of anthocyanin showed the higher consumption.

\section{Ileal protein digestibility}

The results showed that there was no significant interaction between the diet and cage density. The mean value of digestibility of proteins by PSPE level showed a significant effect $(\mathrm{P}<0.05)$. The highest protein digestibility was shown by $\mathrm{A} 1$ at $25 \mathrm{ml} / \mathrm{kg}$ of diet. Digestibility of protein in diet added with PSPE showed better results than the control diet, due to PSPE which contained active compounds such as anthocyanins. These polyphenols have properties as antioxidant and bacteriostatic, that causing better intestinal health. Hajati et al. (2015) reported that the diet with the addition of polyphenol compounds could 
reduce population of $E$. coli bacteria in the ileum, due to bacteriostatic of polyphenolic compounds. Similarly, Viveros et al. (2011) reported that a diet containing polyphenols reduced the population of Lactobacillus sp. and Clostridium sp. The reduction of populations of pathogenic bacteria in the digestive tract could improve gastrointestinal health so did improve digestibility of protein.

It could be seen from the cage density of D1 $\left(8 \mathrm{birds} / \mathrm{m}^{2}\right)$ showed higher digestibility than did D2 $\left(16 \mathrm{birds} / \mathrm{m}^{2}\right)$. The heat stress that occured in the high density was caused by narrow space, although the temperature of cage between high and low density were the same. Panting activity and body temperature was higher in the high density cage. This indicated that the chickens which were kept in high density cages though the same temperature, produced more decisive body temperature which was accompanied by higher panting activity. More panting activity that occured in high density cage indicated that the chickens try to reduce body heat by increasing the respiratory frequency to reduce $\mathrm{CO}_{2}$. This process was known as respiratory alkalosis. Such condition lead to the poor digestibility of protein in chickens reared at a high cage density. Abu-Dieyeh (2006) reported that panting activity was an attempt to remove heat and caused a decrease in digestibility. High body temperature (rectal) at high cage density decreased metabolism of the body to digest feed. According to Har et al. (2000), the broiler chickens which were exposed to the heat have a shorter rate of passage when it passed through the small intestine.

\section{Meat protein mass}

The addition of PSPE and cages density showed no significant interaction on the meat protein mass. Meat protein mass broiler which was added by PSPE of $25 \mathrm{ml} / \mathrm{kg}$ diet (A1) showed the highest value (Table 2), while the treatment without PSPE (A0) was not differ from the treatment PSPE of $50 \mathrm{ml} / \mathrm{kg}$ diet (A2). The high meat protein mass of A1 indicated that the protein was highly absorbed, supported by the consumption of protein and also the highest protein digestibility. The treatment of A1 (6,5 $\mathrm{mg}$ anthocyanin) can be assumed to be an appropriate measure to support the deposition of meat than A2 (13 mg anthocyanin), because the active substances anthocyanin (flavonoids) contained in PSPE increased health of livestock, so the substance supported the process of nutrients absorption, especially protein, which also increased the intake of protein as a substrate for meat deposition. Syafitri et al. (2015) reported that chickens fed diet containing flavonoids were able to reduce the $E$. coli bacteria that caused the healthier digestive tract and increased the absorption of nutrients, especially protein, as a substrate for deposition process of protein.

The digestibility of protein is also supported by the calcium consumption that both were the highest in A1. The phenomenon of protein digestibility and the intake of calcium which were related to the meat protein mass in A1 showed that the high protein intake could also bind calcium. It was known as calcium binding protein $(\mathrm{CaBP})$. Syafitri et al. (2015) reported that broiler given beluntas leaves containing flavonoids contribute to the absorption of calcium for meat deposition. However, meat protein mass in chicken given diet without addition of PSPE (A0) showed similar results to that added with PSPE of 50 $\mathrm{m} 1 / \mathrm{kg}$ diet (A2) and lower than A1. Meat protein mass that was lower in A0 was caused by the consumption and digestibility of protein that were also low, so that the protein intake was also low. This gives no support for the meat deposition. The phenomenon in A2 was different although using PSPE, but it is assumed that it was not given at appropriate level that caused lower meat protein mass than A1. This was in line with the research done by Maphosa et al. (2003) that the broiler chicken given too high level of purple sweet potato 
could decrease protein of meat and live weight. Surai (2013) reported that component containing polyphenolic compounds gave antinutritive effects, when given at too high doses, because polyphenolic compounds that were composed by reactive hydroxyl bonding that could interact with the carbonyl group of the endogenous protein (digestive enzymes and proteins found in the intestines), therefore, it reduced the protein digestibility and chickens performance.

Meat protein mass was not significantly $(\mathrm{P}>0.05)$ influenced by cage density. It meant that the cage density had no impact on the ability of the protein deposition in the form of meat protein mass. Although the protein digestibility at lower cage density indicated a higher value, the calcium intake was not different either in the low or high density. The same mass meat protein between low and high density gave the meaning that the chickens were not exposed to continuous stress and able to adapt the ambient temperature by panting activity. This condition was supported by the high panting activity at 6-18 hours and significantly different between low and high density, while at 18-6 hours showed the same lower results, so it could not be assumed that there was disrupted process of protein metabolism. Tamzil (2014) reported that the chickens kept at the high ambient temperature could cause heat stress, so that the chickens tried to eliminate the body heat by insensible heat loss through the panting activity (75\%) and sensible heat loss through radiation (25\%) to maintain the stable body temperature.

\section{CONCLUSION}

It is concluded that the addition of purple sweet potato extract up to the level of 25 $\mathrm{ml} / \mathrm{kg}$ diet gave the highest consumption of protein, protein digestibility, and the meat protein mass.

\section{REFERENCES}

Abu-Dieyeh ZH. 2006. Effect of high temperature per se on growth performance of broilers. Int J Poult Sci. 5:19-21.

Amrullah IK. 2004. Nutrisi Ayam Broiler. Bogor (Indonesia): Lembaga Satu Gunung Budi.

Baskan KS, Tutem E, Akyuz E, Apak R. 2015. Assesment of the contributions of anthocyanins to the total antioxidants capacities of plant foods. Eur Food Res Technol. 241:529-541.

Brickett KE, Dahiya JP, Classen HL, Gomis S. 2007. Influence of dietary nutrient density, feed form, and lighting on growth and meat yield of broiler chickens. Poult Sci. 86:2172-2181.

Collier RJ, Collier JL. 2012. Enviromental physiology of livestock. Hoboken (USA): WileyBlackwell.

Foltyn M, Lichovnikova M, V Rada, Musilova A. 2015. Apparent ileal digestibility of protein and amino acids in protein feedstuffs and trypsin activity in the small intestine in broiler chickens. Czech J Anim Sci. 60:375-382.

Hajati H, Hassanabadi A, Golian AG, Nassiri-Moghaddam H, Nassiri MR. 2015. The effect of grape seed extract and vitamin c feed supplements carcass characteristics, gut morphology and ileal microflora in broiler chickens exposed to chronic heat stress. Iran J Appl Anim Sci. 5:155-165.

Har L, Rong D, Zhang ZY. 2000. The effect of thermal environment on the digestion of broilers. Anim Physiol. 83:57-64.

Ji H, Zhang H, Li H, Li Y. 2015. Analysis on the nutrition composition and antioxidant activity of different types of sweet potato cultivars. Food Nutr Sci. 6:161-167. 
Khooshechin F, Hosseini SM, Nourmohammadi R. 2015. Effect of dietary acidification in broiler chickens: 1. growth performance and nutrients ileum digestibility. Ital J Anim Sci. 14:423-427.

Loetscher Y, Krouzer M, Messikommer RE. 2013. Oxidative stability of the meat of broilers supplemented with rosemary leaves, rosehip fruits, chokeberry pomace and entire nettle, and effects on performance and meat quality. Poult Sci. 92:2938-2948.

Lu T, Harper AF, Zhao J, Dalloul RA. 2014. Effects of a dietary antioxidant blend and vitamin E on growth performance, oxidative status and meat quality in broiler chickens fed a diet high in oxidants. Poult Sci. 93:1649-1657.

Lv M, Yan L, Wang Z, An S, Wu M, Lv Z. 2015. Effects of feed form and particle size on growth performance, carcass characteristics and digestive tract development of broilers. Anim Nutr. 1:252-255.

Mahfudz LD, Atmomarsono NU, Suthama N. 2015. Interactive effect of cage density and dietary black cumin level on productive efficiency in broiler chickens. J Indones Trop Anim Agric. 40:37-44.

Maphosa T, Gunduza KT, Kusina J, Mutungamiri A. 2003. Evaluation of sweet potato tuber (Ipomea batatas L.) as a feed ingredient in broiler chicken diets. Livest Res Rural Develop. 15:25-34.

Sukamto MB, Yunianto VD. 2013. Kecernaan protein, retensi nitrogen dan massa protein daging ayam broiler yang diberi ransum daun murbei (Morus alba L.) yang difermentasi dengan cairan rumen. J Ilmu Teknol Pet. 3:25-32.

Montilla CE, Hillebrand S, Winterhalter P. 2011. Anthocyanins in purple sweet potato (Ipomea batatas L.) Varieties. Fruit Veget Cereal Sci Biotechnol. 5:19-24.

Rierson RD. 2011. Broiler preference for light color and feed form, and the effect of light on growth and performance of broiler chicks. (Thesis). Manhattan (USA): Kansas State University.

Scott ML, Nesheim MC, Young RJ. 1982. Nutrition of The Chicken. 2nd Ed. New York (USA): M.L. Association.

Stein HH, Seve B, Fuller MF, Moughan PJ, De Lange CFM. 2007. Amino acid bioavaibility and digestibility in pig feed ingredients: Terminolog and application. J Anim Sci. 85:172-180.

Surai PF. 2013. Polyphenols compound in the chicken/animal diet: from the past to the future. $\mathbf{J}$ Anim Physiol Anim Nutr. 98:19-31.

Suthama N. 2003. Metabolisme protein pada ayam kampung periode pertumbuhan yang diberi ransum memakai dedak padi fermentasi. J Pengemb Pet Trop. 10:44-48.

Syafitri YE, Yunianto VD, Suthama N. 2015. Pemberian ekstrak daun beluntas (Pluchea indica less) dan klorin terhadap massa kalsium dan massa protein daging pada ayam broiler. Anim Agric J. 4:155-164.

Tamzil MH. 2014. Stress panas pada unggas: metabolisme, akibat dan upaya penanggulangannya. Wartazoa. 24:57-66.

Tillman AD, Hartadi H, Reksohadiprodjo S, Prawirokusumo S, Lebdosoekojo S. 2005. Ilmu makanan ternak dasar. Yogyakarta (Indonesia): Gadjah Mada University Press.

Viveros A, Chamorro S, Pizarro M, Arija I, Centeno C, Brenes A. 2011. Effects of dietary polyphenol-rich grape products on intestinal microflora and gut morphology in broiler chicks. Poult Sci. 90:566-578.

Wada N, Sakamoto T, Matsugo S. 2015. Mycosporine-like amino acids and their derivatives as natural antioxidants. Antioxidants. 4:603-646. 